\title{
Mammographic density: a potential monitoring biomarker for adjuvant and preventative breast cancer endocrine therapies
}

\author{
Michael S. Shawky ${ }^{1,2}$, Hilary Martin ${ }^{3}$, Honor J. Hugo ${ }^{4,5}$, Thomas Lloyd6, Kara L. \\ Brittt $^{7,8,9}$, Andrew Redfern ${ }^{3, *}$ and Erik W. Thompson ${ }^{4,5,10, *}$ \\ ${ }^{1}$ Department of Head and Neck and Endocrine Surgery, Faculty of Medicine, University of Alexandria, Egypt \\ 2 Department of Surgery, University College Hospital, London, UK \\ ${ }^{3}$ School of Medicine and Pharmacology, University of Western Australia, and Department of Medical Oncology, Fiona Stanley \\ Hospital, Perth, Western Australia, Australia \\ ${ }^{4}$ Institute of Health and Biomedical Innovation and School of Biomedical Sciences, Queensland University of Technology, \\ Australia \\ ${ }^{5}$ Translational Research Institute, Brisbane, Australia \\ ${ }^{6}$ Department of Radiology, Princess Alexandra Hospital, Brisbane, Australia \\ 7 The Sir Peter MacCallum Department of Oncology, University of Melbourne, Melbourne, Australia \\ ${ }^{8}$ Peter MacCallum Cancer Centre, Melbourne, Australia \\ 9 Department of Anatomy and Developmental Biology, Monash University, Melbourne, Australia \\ ${ }^{10}$ Department of Surgery, University of Melbourne, St Vincent's Hospital, Melbourne, Australia \\ * These authors have contributed equally to this work \\ Correspondence to: ErikWThompson, email: e2.thompson@qut.edu.au \\ Keywords: mammographic density, breast cancer, endocrine therapy, predictive biomarker, surrogate \\ Received: October 04, $2016 \quad$ Accepted: October 08, $2016 \quad$ Published: November 21, 2016
}

\section{ABSTRACT}

Increased mammographic density (MD) has been shown beyond doubt to be a marker for increased breast cancer risk, though the underpinning pathobiology is yet to be fully elucidated. Estrogenic activity exerts a strong influence over MD, which consequently has been observed to change predictably in response to tamoxifen anti-estrogen therapy, although results for other selective estrogen receptor modulators and aromatase inhibitors are less consistent. In both primary and secondary prevention settings, tamoxifen-associated MD changes correlate with successful modulation of risk or outcome, particularly among pre-menopausal women; an observation that supports the potential use of MD change as a surrogate marker where short-term MD changes reflect longer-term anti-estrogen efficacy. Here we summarize endocrine therapy-induced MD changes and attendant outcomes and discuss both the need for outcome surrogates in such therapy, as well as make a case for MD as such a monitoring marker. We then discuss the process and steps required to validate and introduce MD into practice as a predictor or surrogate for endocrine therapy efficacy in preventive and adjuvant breast cancer treatment settings.

\section{INTRODUCTION}

Breast cancer (BC) is the most common cancer in women and the second leading cause of cancer-related death among females in the US according to 2016 statistics [1]. Latest global cancer statistics show that 1.7 million $\mathrm{BC}$ diagnoses and 522,000 BC-related deaths were recorded in 2012, with a $20 \%$ increase in the $\mathrm{BC}$ incidence rate and $14 \%$ increase in the BC-related mortality rate, in comparison with 2008 estimates [2]. Such striking statistics highlight the importance of optimizing the prevention and treatment of this disease.

Approximately $60-75 \%$ of $\mathrm{BCs}$ are hormone receptor positive, expressing estrogen receptor (ER), progesterone receptor (PR) or both [3]. In keeping with this, cumulative estrogen exposure has consistently been demonstrated to elevate $\mathrm{BC}$ risk such that doubling of serum estrogen raises BC relative risk by 1.29 fold [4]. Factors that modulate estrogen exposure throughout life, including endogenous elements such as age of 
menarche and menopause, breast feeding and postmenopausal obesity, and exogenous elements such as oral contraceptives and hormone replacement therapy (HRT), all influence $\mathrm{BC}$ risk in a direction predictable by their impact on estrogen levels [5].

Predictably then, endocrine therapy (ET) may be used both to reduce the risk of contracting such cancers $[6,7]$ as well as to attenuate the risk of their return after surgery for early stage disease [8]. A choice of agents needs to be made, particularly between the selective ER modulator (SERM) tamoxifen and the aromatase inhibitors (AIs), which suppress post-menopausal estrogen synthesis. This is in the context of treatment over 5 to 10 years, sometimes with significant toxicity and with no method of ascertaining whether a particular treatment strategy is effective or futile until the advent of BC occurrence/ recurrence or otherwise. For this reason, numerous BC biomarkers have been studied to guide both the utility of ET overall as well as agent choice, although to date only the presence of ER and PR are used to predict overall benefit in the clinic and no biomarker guides agent choice.

On this background, mammographic density (MD) shows significant promise as a tool to refine ET decisions. MD is an imaging parameter that reflects the relative amounts of various tissue elements in the breast. It is well established that radiographic MD histologically corresponds to higher fractions of stroma and epithelium relative to adipose tissue [9]. It has also been demonstrated to correlate directly and incrementally with BC risk [10] in such a way that for every 3-6\% MD rise, relative $\mathrm{BC}$ risk increases by $10 \%$ [11]. In addition to demonstrating utility in predicting the initial risk of $\mathrm{BC}$ [12], MD at diagnosis also correlates with subsequent risk of local but not distant relapse [13].

Higher MD, which correlates with increasing BC risk, has been documented in post-menopausal women receiving exogenous estrogen as a replacement therapy $[14,15]$, as well as among non-HRT users with higher levels of endogenous estrogen [16]. In addition, more frequent expression of $\mathrm{ER} \alpha$ has been found in the stroma of the risk-associated higher MD mammary tissue [17]. Thus, an intrinsic causal link appears likely within this triad of higher estrogen activity, high MD and elevated $\mathrm{BC}$ risk. It therefore follows that gaining a greater understanding of the underlying pathobiology linking $\mathrm{MD}$ and $\mathrm{BC}$, and how estrogens and anti-estrogens may broker that link, could give us new insights into improved therapeutic approaches against the disease beyond prediction of risk.

As defined by the Biomarker Definition Working Group of the National Institute of Health, USA, a biomarker is any objectively measurable characteristic that could indicate an underlying physiological or pathological process (e.g. BC risk) or evaluate the response to an intervention (e.g. ET) [18]. Two concepts should be distinguished, that of a prognostic marker, which informs about the native risk of certain outcomes in the absence of any intervention, to be differentiated from a predictive marker which predicts response to an intervention [19]. Importantly, the FDA considers surrogate markers in the approval process, measurable parameters that may be used as a substitute for clinically relevant endpoints in interventional trials, essentially synonymous with predictive markers [20]. For a biomarker to be validated as "predictive", correlation with outcome needs to be evaluated in clinical trials treating the disease where the intervention is randomly allocated to the subjects, ideally with the biomarker study forming part of the prospective design [21]. A control group is essential for full predictive biomarker evaluation, excluding the possibility that correlations between biomarker and outcome are not purely due to a prognostic effect.

There is a surfeit of commonly employed prognostic biomarkers used to gauge the risk of both $\mathrm{BC}$ incidence, such as family history and prior breast biopsy [22]; or relapse, such as lymph node involvement, size and grade of tumour [23]. In contrast, there is a dearth of predictive markers for ET efficacy in these scenarios. In addition to data indicating predictive ability, a potential biomarker that could indicate ET efficacy would ideally fulfil the following criteria: 1) biologically plausible [24], that is an intrinsic link to $\mathrm{BC}$ therapeutic biology would account for the prediction of ET-mediated protective effect, 2) serially measurable, such that it can be practically used to indicate whether the ET-mediated risk-modifying process is proceeding in a favourable way relatively early in therapy, when tailoring of the preventive intervention can still be undertaken i.e. before $\mathrm{BC}$ occurrence or recurrence, and 3) applicable to both the preventive and adjuvant settings.

Immunohistochemical (IHC) biomarkers such as ER expression [25] and STAT5 expression [26] are indeed helpful for deciding which patients may benefit from ET on pathogenesis related grounds and thus fulfil criterion 1, although they do not provide guidance on ET agent choice. However, being inherent characteristics of the initial tumour, such biomarkers are not useful as monitoring tools as change cannot be measured to reflect ET action and they are not useful in the preventive setting as there is no actual tumour to assess. Although MD has plausible biological links to breast cancer risk (criterion 1), unlike these biomarkers it cannot be used to specifically select patients likely to benefit from ET prior to treatment in the adjuvant setting. In contrast, however, MD may be measured through the treatment period, with MD change potentially reflecting ET efficacy (criterion 2). Additionally, being a character of the "breast" rather than the "tumour" with pathogenic links to BC risk, MD change may be used to predict ET efficacy in the preventive setting (criterion 3 ) and serial monitoring of the unaffected breast maintains MD utility in the adjuvant setting after surgical excision of the cancerous breast tissue (criterion 3). Thus, MD is intuitively a compelling 
Table 1: Studies investigating MD changes in response to use of SERMs

\begin{tabular}{|c|c|c|c|c|c|c|c|c|c|c|c|}
\hline \multirow{2}{*}{\multicolumn{2}{|c|}{ Study }} & \multirow{4}{*}{$\begin{array}{l}\text { Subjects } \\
\text { Age (yr) } \\
\text { Clinical } \\
\text { Scenario }\end{array}$} & \multicolumn{5}{|l|}{ Protocol } & \multicolumn{4}{|c|}{ Results (PMD Change) } \\
\hline & & & \multirow{2}{*}{\multicolumn{2}{|c|}{ Mammography }} & \multirow{3}{*}{ Agent and dose } & \multirow{3}{*}{$\begin{array}{l}\text { Time } \\
\text { On } \\
\text { Therapy }\end{array}$} & \multirow{3}{*}{$\mathbf{N}$} & \multicolumn{2}{|c|}{ PMD (\%) } & \multicolumn{2}{|l|}{$p$ value } \\
\hline \multirow[b]{2}{*}{ Reference } & \multirow{2}{*}{$\begin{array}{l}\text { Trial } \\
\text { Type }\end{array}$} & & & & & & & & & & \\
\hline & & & Measure & $\begin{array}{l}\text { Post- } \\
\text { Start }\end{array}$ & & & & Baseline & Finish & baseline & control \\
\hline \multicolumn{12}{|c|}{ Tamoxifen } \\
\hline $\begin{array}{c}\text { Brisson } \\
2000[28]\end{array}$ & $\mathrm{RCT}$ & $\begin{array}{c}\geq 35 \\
\text { Prevention }\end{array}$ & $\begin{array}{l}\text { PMD, } \\
\text { Wolfe } \\
\end{array}$ & $41 \mathrm{~m}$ & $\begin{array}{c}\text { Placebo } \\
\text { Tamoxifen } 20 \mathrm{mg} \\
\end{array}$ & $60 \mathrm{~m}$ & $\begin{array}{l}33 \\
36 \\
\end{array}$ & $\begin{array}{l}60.5 \\
60.3 \\
\end{array}$ & $\begin{array}{l}51.1 \\
56.7 \\
\end{array}$ & $\begin{array}{l}\text { NR } \\
\text { NR } \\
\end{array}$ & $\begin{array}{l}\text { NA } \\
0.01 \\
\end{array}$ \\
\hline $\begin{array}{l}\text { Chow } \\
2000[29]\end{array}$ & $\mathrm{RCT}$ & $\begin{array}{c}\text { 36-74 } \\
\text { Prevention }\end{array}$ & $\begin{array}{c}\text { PMD } \\
\text { Boyd, } \\
\text { BIRADS }\end{array}$ & $22 \mathrm{~m}$ & $\begin{array}{c}\text { Control } \\
\text { Tamoxifen } 20 \mathrm{mg}\end{array}$ & $24 \mathrm{~m}$ & $\begin{array}{l}20 \\
27\end{array}$ & $\begin{array}{l}29.7 \\
31.9\end{array}$ & $\begin{array}{l}29.6 \\
29.2\end{array}$ & $\begin{array}{c}0.88 \\
0.0007\end{array}$ & $\begin{array}{l}\text { NA } \\
\text { NR }\end{array}$ \\
\hline $\begin{array}{l}\text { Konez } \\
2001[31]\end{array}$ & $\begin{array}{l}\text { Retro } \\
\text { cohort }\end{array}$ & $\begin{array}{c}\text { 31-81 } \\
\text { Adjuvant } \\
\text { post-BC }\end{array}$ & $\begin{array}{c}\text { MD } \\
\text { Category }\end{array}$ & $60 \mathrm{~m}$ & Tamoxifen 20mg & $60 \mathrm{~m}$ & 24 & \multicolumn{2}{|c|}{$20.8 \% *$} & 0.06 & NA \\
\hline $\begin{array}{c}\text { Cuzick } \\
2004[27]\end{array}$ & $\mathrm{RCT}$ & $\begin{array}{c}35-70 \\
\text { Prevention }\end{array}$ & $\begin{array}{l}\text { PMD, } \\
\text { Boyd }\end{array}$ & $54 \mathrm{~m}$ & $\begin{array}{c}\text { Placebo } \\
\text { Tamoxifen } 20 \mathrm{mg}\end{array}$ & $60 \mathrm{~m}$ & $\begin{array}{l}430 \\
388 \\
\end{array}$ & $\begin{array}{l}42.6 \\
41.9 \\
\end{array}$ & $\begin{array}{l}35.3 \\
28.2 \\
\end{array}$ & $\begin{array}{l}<0.001 \\
<0.001 \\
\end{array}$ & $\begin{array}{c}\text { NA } \\
<0.001 \\
\end{array}$ \\
\hline $\begin{array}{l}\text { Meggiorini } \\
2008[30]\end{array}$ & $\begin{array}{l}\text { Retro } \\
\text { cohort }\end{array}$ & $\begin{array}{c}41-78 \\
\text { Adjuvant } \\
\text { post-BC }\end{array}$ & BIRADS & $12 \mathrm{~m}$ & $\begin{array}{c}\text { Control } \\
\text { Tamoxifen } 20 \mathrm{mg}\end{array}$ & $60 \mathrm{~m}$ & $\begin{array}{l}80 \\
68\end{array}$ & \multicolumn{2}{|c|}{$\begin{array}{l}30 \% * \\
50 \% *\end{array}$} & $\begin{array}{l}\text { NR } \\
\text { NR }\end{array}$ & $\begin{array}{l}\text { NA } \\
0.021\end{array}$ \\
\hline $\begin{array}{c}\text { Howell } \\
2015[33]\end{array}$ & $\begin{array}{l}\text { Retro } \\
\text { cohort }\end{array}$ & $\begin{array}{c}33-46 \\
\text { Prevention }\end{array}$ & PMD & $12 \mathrm{~m}$ & Tamoxifen & $12 \mathrm{~m}$ & 105 & \multicolumn{2}{|c|}{$49 \% \%^{\dagger}$} & NR & NA \\
\hline $\begin{array}{l}\text { Engman } \\
2016[32]\end{array}$ & $\begin{array}{l}\text { Retro } \\
\text { cohort }\end{array}$ & $\begin{array}{c}45-60 \\
\text { Adjuvant } \\
\text { post-BC }\end{array}$ & $\begin{array}{l}\text { VPD, } \\
\text { DV }\end{array}$ & annually & Tamoxifen & $36 \mathrm{~m}$ & 379 & $\begin{array}{l}11.6 \\
64.7\end{array}$ & $\begin{array}{l}17 \% * * \\
0,90 * *\end{array}$ & $\begin{array}{l}\text { NR } \\
\text { NR }\end{array}$ & $\begin{array}{l}\text { NR } \\
\text { NR }\end{array}$ \\
\hline \multicolumn{12}{|c|}{ Raloxifene } \\
\hline $\begin{array}{l}\text { Freedman } \\
2001[39]\end{array}$ & $\mathrm{RCT}$ & $\begin{array}{c}45-60 \\
\text { Prevention } \\
\text { Post- } \\
\text { menopause }\end{array}$ & PMD & $24 \mathrm{~m}$ & $\begin{array}{c}\text { Placebo } \\
\text { Raloxifene } 60 \mathrm{mg} \\
\text { Raloxifene } 150 \mathrm{mg}\end{array}$ & $24 \mathrm{~m}$ & $\begin{array}{l}45 \\
45 \\
42\end{array}$ & $\begin{array}{l}9.8 \\
9.3 \\
8.1\end{array}$ & $\begin{array}{l}8.5 \\
7.7 \\
6.4\end{array}$ & $\begin{array}{l}<0.02 \\
<0.02 \\
<0.02\end{array}$ & $\begin{array}{l}\text { NA } \\
\text { NS } \\
\text { NS }\end{array}$ \\
\hline $\begin{array}{l}\text { Christo- } \\
\text { doulakos } \\
2002[38]\end{array}$ & $\mathrm{RCT}$ & $\begin{array}{c}41-67 \\
\text { Risk of } \\
\text { osteoporosis } \\
\end{array}$ & Wolfe & $12 \mathrm{~m}$ & $\begin{array}{c}\text { Placebo } \\
\text { Raloxifene } 60 \mathrm{mg} \\
\text { Tibilone } 2.5 \mathrm{mg} \\
\end{array}$ & $12 \mathrm{~m}$ & $\begin{array}{l}27 \\
48 \\
56 \\
\end{array}$ & $\begin{array}{l}25.9^{\dagger} \\
18.8^{\dagger} \\
10.7^{\dagger}\end{array}$ & $\begin{array}{c}0^{\dagger \dagger} \\
6.3^{\dagger \dagger} \\
10.7^{\dagger \dagger}\end{array}$ & $\begin{array}{l}\text { NR } \\
\text { NR } \\
\text { NR }\end{array}$ & $\begin{array}{l}\text { NA } \\
0.47 \\
0.07 \\
\end{array}$ \\
\hline $\begin{array}{c}\text { Cirpan } \\
2006[37]\end{array}$ & $\begin{array}{l}\text { Retro } \\
\text { cohort }\end{array}$ & $\begin{array}{c}43-58 \\
\text { Osteoporosis }\end{array}$ & BIRADS & $12 \mathrm{~m}$ & Raloxifene $60 \mathrm{mg}$ & $12 \mathrm{~m}$ & 55 & \multicolumn{2}{|c|}{$\begin{array}{l}\text { MD category increase } \\
\text { in one patient. } \\
\text { Otherwise, no change }\end{array}$} & 0.32 & NA \\
\hline $\begin{array}{c}\text { Eng-Wong } \\
2008[40]\end{array}$ & $\mathrm{CT}$ & $\begin{array}{c}35-47 \\
\text { Prevention }\end{array}$ & PMD & $24 \mathrm{~m}$ & Raloxifene $60 \mathrm{mg}$ & $24 \mathrm{~m}$ & 27 & 38 & 41.5 & NS & NA \\
\hline $\begin{array}{l}\text { Eilertsen } \\
2008[36]\end{array}$ & $\mathrm{RCT}$ & $\begin{array}{c}45-65 \\
\text { Prevention }\end{array}$ & $\begin{array}{c}\text { PMD } \\
\text { (volume) }\end{array}$ & 12 week & $\begin{array}{c}\text { Raloxifene } 60 \mathrm{mg} \\
\text { Low dose HRT } \\
\text { Standard dose HRT }\end{array}$ & 12 week & $\begin{array}{l}44 \\
44 \\
45 \\
\end{array}$ & $\begin{array}{l}7.7 \\
8.6 \\
8.3 \\
\end{array}$ & $\begin{array}{c}8.1 \\
11.2 \\
10.6 \\
\end{array}$ & $\begin{aligned} & 0.09 \\
&< 0.0001 \\
&< 0.0001 \\
&\end{aligned}$ & $\begin{array}{l}\text { NA } \\
\text { NA } \\
\text { NA } \\
\end{array}$ \\
\hline $\begin{array}{l}\text { Nielsen } \\
2009[35]\end{array}$ & $\mathrm{RCT}$ & $\begin{array}{c}55-80 \\
\text { Risk of } \\
\text { osteoporosis }\end{array}$ & $\begin{array}{c}\text { PMD } \\
\text { BIRADS }\end{array}$ & $24 \mathrm{~m}$ & $\begin{array}{c}\text { Tibolone } \\
\text { Raloxifene } 60 \mathrm{mg} \\
\text { Estradiol } 0.014 \mathrm{wk},\end{array}$ & $24 \mathrm{~m}$ & $\begin{array}{c}45 \\
135 \\
135 \\
\end{array}$ & $\begin{array}{l}7.5 \\
16 \\
16 \\
\end{array}$ & $\begin{array}{l}8.1 \\
18 \\
20 \\
\end{array}$ & $\begin{array}{c}0.9 \\
\mathrm{NS} \\
<0.05 \\
\end{array}$ & $\begin{array}{l}\text { NA } \\
\text { NA } \\
\text { NA }\end{array}$ \\
\hline $\begin{array}{c}\text { Harvey } \\
2013[34]\end{array}$ & $\mathrm{RCT}$ & $\begin{array}{c}40-75 \\
\text { Risk of } \\
\text { osteoporosis }\end{array}$ & PMD & $24 \mathrm{~m}$ & $\begin{array}{c}\text { Placebo } \\
\text { BZA 20mg/E } 0.45 \mathrm{mg} \\
\text { BZA 20mg/E0.625 mg } \\
\text { Raloxifene } 60 \mathrm{mg}\end{array}$ & $24 \mathrm{~m}$ & $\begin{array}{l}126 \\
129 \\
105 \\
125 \\
\end{array}$ & $\begin{array}{l}26.1 \\
26.5 \\
25.3 \\
27.2\end{array}$ & $\begin{array}{c}25.7 \\
26.1 \\
25.2 \\
27\end{array}$ & \begin{tabular}{|c|} 
significant \\
significant \\
NS \\
NS \\
\end{tabular} & $\begin{array}{l}\text { NA } \\
\text { NS } \\
\text { NS } \\
\text { NS }\end{array}$ \\
\hline
\end{tabular}

$* \%$ pts with MD category reduction, $\uparrow \%$ pts with MD decrease, **annualized MD reduction, $\dagger \%$ pts with MD increase RCT: Randomised Controlled Trial, Retro cohort: Retrospective cohort, BC: Breast Cancer, PMD: Percent Mammographic Density, BIRADS: Breast Imaging-Reporting and Data System, VPD: Volumetric Percent Density, DV: Dense Volume, m: month, HRT: Hormone Replacement Therapy, BZA: Bazedoxifene, NS: Not Significant, NR: Not Reported, NA: Not Applicable

biomarker for monitoring the response to ET in patients selected for therapy. Such therapy may be dictated by MD stratification of risk in primary prevention and according to ER and PR status in the adjuvant setting.

In this article, we have reviewed the MD changes in relation to the spectrum of ETs employed in different BC scenarios to explore whether evidence to date supports this hypothesis and, if this proves to be the case, to ascertain what further research is required to bring this into routine practice. Specific aims of the review are to:

1) Look at degree and timeframe of MD change with currently employed ETs.
2) Assess the utility of serial MD measurements for predicting the primary preventative benefit of chemoprophylaxis in females with elevated BC risk.

3) Assess the effectiveness of serial MD measurement in the follow-up of females with surgically excised early breast cancer on adjuvant ET to prevent recurrence.

4) Explore the mechanisms connecting MD with breast cancer risk and prevention to identify new biological avenues of protection from adverse breast cancer outcomes. 
Table 2: Studies investigating MD changes in response to use of AIs

\begin{tabular}{|c|c|c|c|c|c|c|c|c|c|c|c|}
\hline \multirow{2}{*}{\multicolumn{2}{|c|}{ Study }} & \multirow{4}{*}{$\begin{array}{c}\text { Subjects } \\
\text { Age (year) }\end{array}$} & \multicolumn{5}{|c|}{ Protocol } & \multicolumn{4}{|c|}{ Results (PMD Change) } \\
\hline & & & \multirow{2}{*}{\multicolumn{2}{|c|}{ Mammography }} & \multirow{3}{*}{ Agent and dose } & \multirow{3}{*}{\begin{tabular}{|c|} 
Time \\
On \\
Therapy
\end{tabular}} & \multirow{3}{*}{$\mathbf{N}$} & \multicolumn{2}{|c|}{ PMD (\%) } & \multicolumn{2}{|c|}{$p$ value } \\
\hline \multirow[b]{2}{*}{ Reference } & \multirow{2}{*}{$\begin{array}{l}\text { Trial } \\
\text { Type }\end{array}$} & & & & & & & & & & \\
\hline & & & Measure & \begin{tabular}{|l} 
Post- \\
Start
\end{tabular} & & & & Baseline & Finish & baseline & control \\
\hline $\begin{array}{l}\text { Vachon } \\
2007[45]\end{array}$ & $\mathrm{RCT}$ & $\begin{array}{l}\text { 30-84, post- } \\
\text { tamoxifen } \\
\text { Adjuvant post-BC }\end{array}$ & PMD & $12 \mathrm{~m}$ & $\begin{array}{c}\text { Placebo } \\
\text { Letrozole } 2.5 \mathrm{mg}\end{array}$ & $60 \mathrm{~m}$ & $\begin{array}{l}33 \\
35\end{array}$ & $\begin{array}{c}20 \\
18.5\end{array}$ & $\begin{array}{c}19 \\
16.9\end{array}$ & $\begin{array}{l}\text { NR } \\
\text { NR }\end{array}$ & $\begin{array}{l}\text { NA } \\
0.58\end{array}$ \\
\hline $\begin{array}{l}\text { Cigler } \\
2010[46]\end{array}$ & $\mathrm{RCT}$ & $\begin{array}{l}\text { Post-menopausal } \\
\text { Prevention }\end{array}$ & $\begin{array}{c}\text { PMD } \\
\text { Boyd, BIRADS }\end{array}$ & $24 \mathrm{~m}$ & $\begin{array}{c}\text { Placebo } \\
\text { Letrozole } 2.5 \mathrm{mg}\end{array}$ & $12 \mathrm{~m}$ & $\begin{array}{l}16 \\
27\end{array}$ & $\begin{array}{c}40 \\
39.6\end{array}$ & $\begin{array}{l}38.7 \\
39.6\end{array}$ & $\begin{array}{l}0.71 \\
0.99\end{array}$ & $\begin{array}{l}\text { NA } \\
0.69\end{array}$ \\
\hline $\begin{array}{c}\text { Cigler } \\
2011[47]\end{array}$ & $\mathrm{RCT}$ & $\begin{array}{l}\text { Post-menopause } \\
\text { Prevention }\end{array}$ & $\begin{array}{c}\text { PMD } \\
\text { Boyd, BIRADS }\end{array}$ & $12 \mathrm{~m}$ & $\begin{array}{c}\text { Control } \\
\text { Exemestane } 25 \mathrm{mg}\end{array}$ & $12 \mathrm{~m}$ & $\begin{array}{l}31 \\
34 \\
\end{array}$ & $\begin{array}{l}36.5 \\
33.9\end{array}$ & $\begin{array}{l}37.1 \\
34.5\end{array}$ & $\begin{array}{l}\text { NR } \\
\text { NR }\end{array}$ & $\begin{array}{l}\text { NA } \\
0.91\end{array}$ \\
\hline $\begin{array}{c}\text { Smith } \\
\text { 2012[43] }\end{array}$ & CT & $\begin{array}{l}\text { Mean } 58.9 \\
\text { Prevention }\end{array}$ & PMD & $12 \mathrm{~m}$ & Letrozole $2.5 \mathrm{mg}$ & $12 \mathrm{~m}$ & 16 & 27.7 & 23 & 0.036 & NA \\
\hline $\begin{array}{c}\text { Gatti-Mays } \\
2016[44]\end{array}$ & $\begin{array}{c}\text { Phase II } \\
\text { trial }\end{array}$ & $\begin{array}{c}\text { Post-menopausal } \\
\text { Prevention }\end{array}$ & PMD & $24 \mathrm{~m}$ & Exemestane $25 \mathrm{mg}$ & $24 \mathrm{~m}$ & 35 & 32.5 & 28.4 & 0.009 & NA \\
\hline $\begin{array}{l}\text { Engman } \\
2016[32]\end{array}$ & $\begin{array}{l}\text { Retro } \\
\text { cohort }\end{array}$ & $\begin{array}{c}58-71 \\
\text { Adjuvant post-BC }\end{array}$ & $\begin{array}{l}\text { VPD } \\
\text { DV }\end{array}$ & annually & AIs & $36 \mathrm{~m}$ & 425 & $\begin{array}{c}7.2 \\
51.9\end{array}$ & $\begin{array}{c}0.19 \% * \\
0.52 *\end{array}$ & $\begin{array}{l}\mathrm{NR} \\
\mathrm{NR}\end{array}$ & $\begin{array}{l}\text { NR } \\
\text { NR }\end{array}$ \\
\hline
\end{tabular}

*annualized MD reduction

RCT: Randomised Controlled Trial, Retro cohort: Retrospective cohort, BC: Breast Cancer, PMD: Percent Mammographic Density, BIRADS: Breast Imaging-Reporting and Data System, VPD: Volumetric Percent Density, DV: Dense Volume m: month, NR: Not Reported, NA: Not Applicable

\section{RESULTS}

\section{MD change on currently employed ET}

A total of 19 publications recorded MD changes across periods of ET. Table 1 summarizes MD changes on SERMs. With regards to the seven studies exploring changes on tamoxifen, all of which were in populations including pre-menopausal women [27-31], by far the largest study was the IBIS I prevention study accounting for more than two thirds of patients. Significant reductions in all sub-groups were seen on tamoxifen relative to placebo; $7.9 \%$ v $3.5 \%$ at 18 months $(p<0.001)$ and $13.7 \%$ v $7.3 \%$ at 54 months $(p<0.001)$ [27]. The three other trials with placebo or control arms [28-30] all showed significant MD reductions on tamoxifen despite low participant numbers. Two other recent retrospective studies have also demonstrated an annual MD reduction in tamoxifen-treated women [32, 33]. Of interest, the small single study looking at subsequent MD change after tamoxifen completion showed small increases in MD posttamoxifen in $48 \%$ of cases, albeit of unknown prognostic significance [31].

For the alternative SERM raloxifene, six of seven studies have been in post-menopausal patients [34-39]. Although numbers have been low, and comparisons sometimes made with patients on HRT rather than placebo [36], none have shown significant MD changes relative to placebo or baseline in single arm trials. Further, two studies have shown trends to increases rather than decreases of MD on the drug [35, 38]. The single premenopausal study showed no impact of raloxifene on MD
[40]. In keeping with this the head-to head STAR trial, comparing tamoxifen to raloxifene for primary prevention showed a significant modestly inferior protection with raloxifene compared to tamoxifen, although whether individuals experiencing an $\mathrm{MD}$ increase responded poorly is unknown [41].

Despite the proven therapeutic efficacy of aromatase inhibitors (AIs) in the adjuvant setting [42], MD has not been observed to change consistently or significantly in response to these agents (Table 2). Of six relevant studies, three uncontrolled studies showed MD reductions with two reaching significance [32, 43, 44]. Three further trials with control arms demonstrated no MD reduction relative to untreated patients, although numbers in all trials were low [45-47]. To summarize, contrary to the case with tamoxifen, a convincing case for using MD to monitor the effects of AIs and other SERMs is not evident from this assembled data.

\section{Correlations between MD change and primary prevention efficacy}

From our review of the data, only one study has directly linked tamoxifen-induced MD reduction to the subsequent risk of developing BC; the report of Cuzick and colleagues on a nested study from the IBIS I trial of tamoxifen versus placebo in women at high risk of the disease [48]. Here they report a significant $63 \%$ BC risk reduction among tamoxifen users having greater than $10 \% \mathrm{MD}$ reduction (MDR), compared to no risk reduction if MDR was less than 10\% (odd ratios: $0.37 v s$. 1.13 ), as assessed visually in 12-18 month post-treatment mammograms $[48,49]$. No literature was identified 
Table 3: Studies investigating BC risk/outcome modification in relation to ET-induced MD changes

\begin{tabular}{|c|c|c|c|c|c|c|c|c|c|c|c|}
\hline \multicolumn{2}{|c|}{ Study } & \multirow{3}{*}{$\begin{array}{c}\text { Subjects } \\
\begin{array}{c}\text { Age (yrs) } \\
\text { Menopausal } \\
\text { status }\end{array}\end{array}$} & \multicolumn{6}{|c|}{ Protocol } & \multirow{2}{*}{\multicolumn{3}{|c|}{$\frac{\text { Results }}{\text { BC-Related Outcomes }}$}} \\
\hline \multirow[b]{2}{*}{ Reference } & \multirow[b]{2}{*}{ Type } & & \multicolumn{3}{|c|}{ Mammography } & \multirow[b]{2}{*}{ Event } & \multirow[b]{2}{*}{ Medication } & \multirow[b]{2}{*}{$\mathbf{N}$} & & & \\
\hline & & & Method & $\underset{\mathbf{R x}}{\text { Time on }}$ & $\begin{array}{l}\text { MD Change } \\
\text { Categories }\end{array}$ & & & & $\begin{array}{c}\text { HR } \\
\text { (MDR v } \\
\text { not) }\end{array}$ & \begin{tabular}{|c|c|}
$\mathbf{9 5 \%}$ \\
$\mathbf{C I}$
\end{tabular} & $\mathbf{p}$ \\
\hline \multicolumn{12}{|c|}{ Preventive - Women at high $\mathrm{BC}$ risk } \\
\hline $\begin{array}{c}\text { Cuzick } \\
\text { 2011[48] }\end{array}$ & $\begin{array}{c}\text { Case } \\
\text { cont } \\
\text { within } \\
\text { RCT }\end{array}$ & $\begin{array}{l}35-70 \\
\text { Mixed }\end{array}$ & $\begin{array}{l}\text { PMD } \\
\text { (PDA) }\end{array}$ & $12-18 \mathrm{~m}$ & $\begin{array}{c}\text { MDR } \geq 10 \% \\
\text { v no decrease }\end{array}$ & $\mathrm{BC}$ risk & Tamoxifen & 507 & 0.32 & $0.14-0.72$ & 0.001 \\
\hline \multicolumn{12}{|c|}{ Adjuvant - Hormone receptor positive early breast cancer } \\
\hline$\underset{2012[57]}{\operatorname{Kim}}$ & $\begin{array}{l}\text { Retro } \\
\text { cohort }\end{array}$ & $\begin{array}{l}25-78 \\
\text { Mixed }\end{array}$ & PMD & $13 \mathrm{~m}$ & $\begin{array}{l}\mathrm{MDR} \geq 10 \% \\
\mathrm{v} \mathrm{MDR}<0 \%\end{array}$ & $\mathrm{BCR}$ & $\begin{array}{l}\text { Tamoxifen } \\
\text { or AI }\end{array}$ & $\begin{array}{c}1065 \\
\text { (938 } \\
\text { invasive) } \\
\end{array}$ & 0.44 & $0.22-0.91$ & 0.027 \\
\hline $\begin{array}{c}\text { Ko } \\
2013[56]\end{array}$ & $\begin{array}{l}\text { Retro } \\
\text { cohort }\end{array}$ & $\begin{array}{l}25-78 \\
\text { Mixed }\end{array}$ & BIRADS & $19 \mathrm{~m}$ & $\begin{array}{l}\text { MDR by } 1+ \\
\text { BIRAD category } \\
\text { V no change } \\
\text { BIRAD category }\end{array}$ & BCR & Tamoxifen & $\begin{array}{c}1066 \\
\text { (932 } \\
\text { invasive) }\end{array}$ & 0.36 & $0.18-0.70$ & 0.003 \\
\hline $\begin{array}{c}\mathrm{Li} \\
2013[54]\end{array}$ & $\begin{array}{l}\text { Case } \\
\text { cont }\end{array}$ & $\begin{array}{c}\text { Median 62-63 } \\
\text { Post- } \\
\text { menopause } \\
\end{array}$ & $\mathrm{ADA}$ & $17 \mathrm{~m}$ & $\begin{array}{c}\mathrm{MDR}>20 \% \\
\mathrm{v} \text { MDR }<10 \%\end{array}$ & BCSM & Tamoxifen & 474 & 0.5 & $0.27-0.93$ & 0.017 \\
\hline $\begin{array}{l}\text { Sandberg } \\
2013[55]\end{array}$ & $\begin{array}{l}\text { Case } \\
\text { cont }\end{array}$ & $\begin{array}{c}\mathrm{NR} \\
\text { Post- } \\
\text { menopause } \\
\end{array}$ & PMD & $19 \mathrm{~m}$ & $\begin{array}{c}\mathrm{MDR} \geq 10 \% \\
\mathrm{v} \operatorname{MDR}<10 \%\end{array}$ & $\begin{array}{c}\mathrm{CBC} \\
\text { risk }\end{array}$ & Tamoxifen & 87 & 0.52 & $0.18-1.51$ & NS \\
\hline $\begin{array}{c}\text { Nynate } \\
2015[53]\end{array}$ & $\begin{array}{l}\text { Case } \\
\text { cont }\end{array}$ & $\begin{array}{l}32-87 \\
\text { Mixed }\end{array}$ & $\begin{array}{l}\text { PMD } \\
\text { (PDA) }\end{array}$ & $12 \mathrm{~m}$ & $\begin{array}{c}\text { Tertiles highest } \\
\text { MDR }(>8.7 \%) \\
\text { v lowest MDR } \\
(<0.5 \%)\end{array}$ & BCSM & Tamoxifen & 349 & 0.44 & $0.22-0.88$ & 0.005 \\
\hline $\begin{array}{c}\text { Martin } \\
\text { 2015[58] }\end{array}$ & $\begin{array}{l}\text { Retro } \\
\text { cohort }\end{array}$ & $\begin{array}{l}25-96 \\
\text { Mixed }\end{array}$ & PMD & $11-24 \mathrm{~m}$ & $\begin{array}{l}\text { MDR }>20 \% \\
v \text { MDR }<0 \%\end{array}$ & BCR & $\begin{array}{l}\text { Tamoxifen } \\
\text { or AI }\end{array}$ & 921 & 0.45 & $0.25-0.80$ & 0.006 \\
\hline $\begin{array}{c}\text { Van Nes } \\
2015[59]\end{array}$ & $\begin{array}{l}\text { Retro } \\
\text { cohort } \\
\text { within } \\
\text { RCT }\end{array}$ & $\begin{array}{l}45-91 \\
\text { Post- } \\
\text { menopause }\end{array}$ & $\begin{array}{l}\text { PMD } \\
\text { (PDA) }\end{array}$ & $24 \mathrm{~m}$ & $\begin{array}{c}\text { Pts divided into } 6 \\
\text { categories } \\
\text { No density change } \\
\text { on } \mathrm{Rx}\end{array}$ & BCR & $\begin{array}{l}\text { Tamoxifen } \\
\text { or } \\
\text { Exemestane }\end{array}$ & 377 & $\begin{array}{c}\text { NR } \\
\text { No } \\
\text { density } \\
\text { change }\end{array}$ & NR & NR \\
\hline
\end{tabular}

RCT: Randomised Controlled trial, Retro cohort: Retrospective cohort, MDR: Mammographic Density Reduction, PMD: Percent Mammographic Density, BIRADS: Breast Imaging-Reporting and Data System,PDA: Percent Dense Area, ADA: Absolute Dense Area, BCSM: Breast Cancer Specific Mortality, BCR: Breast Cancer Relapse, CBC: Contralateral Breast Cancer, AI: Aromatase Inhibitor, HR: Hazard ratio NR: Not Reported

regarding MD change in the IBIS II [7] or MAP.3 [42] studies, which have employed anastrozole and exemestane respectively versus placebo for primary $\mathrm{BC}$ prevention. Howell et al subsequently reproduced this spectrum of MD changes on preventative tamoxifen, though highlighted the difficulty of assessing MD consistently in general radiological practice and suggested introducing volumetric methods for clinical usage [33].

\section{Correlations between MD change and adjuvant ET benefit}

Before reviewing the predictive impact of MD change on adjuvant ET efficacy, it is worthwhile to consider first the prognostic impact of MD baseline present at the time of $\mathrm{BC}$ diagnosis. A lower MD has been reported in most studies to be linked to better BC outcomes in terms of lower risk of local recurrence [13, 50], death from all causes [51] and risk of second BC [52], although none have shown a significant association to the risk of distant metastasis or BC-specific mortality. Baseline MD is thus prognostic for certain parameters of outcome.

Turning to the prediction of ET benefit in the adjuvant setting, seven studies have directly assessed $\mathrm{BC}$ outcome measures in relation to ET-induced MD changes (Table 3). Three case-control studies [53-55] and three retrospective cohorts [56-58] have demonstrated an association between MD reduction in response to ETs and better $\mathrm{BC}$ outcomes, in terms of BC-related death, BC recurrence and contra-lateral primary. Risk reductions were uniformly significant and robust for disease free survival (DFS) (0.36-0.52) and overall or BC specific survival (0.44-0.50), although these trials involved mostly tamoxifen and were mostly in younger women. One study failed to demonstrate an association between MD reduction and lowering of recurrence events in response to exemestane or tamoxifen in post-menopausal women, although the MD changes were small [59]. Contrary to this, the studies of Kim et al [57] and interim analysis of a study by members of our group [58], found MD reduction to be a predictor of outcome in mixed tamoxifen and AIs treated cohorts.

Findings from these studies suggest that MD change could be a valuable biomarker for predicting the impact 
of adjuvant tamoxifen on ER positive $\mathrm{BC}$ outcomes in younger women, with more heterogeneous evidence in older post-menopausal women, particularly those on AIs.

\section{Biological processes underlying $\mathrm{MD}$ change, $\mathrm{BC}$ risk and $\mathrm{ET}$ action}

Recent genetic studies have identified certain single nucleotide polymorphisms (SNPs) with overlapping effects on both $\mathrm{BC}$ risk and $\mathrm{MD}$, suggesting that the $\mathrm{BC}$ risk conferred by these loci is at least partly mediated through their effects on MD [60]. Polymorphisms of genes involved in epidermal growth factor (EGF), ER and insulin-like growth factor 1 (IGF1) signalling, cell proliferation, and migration are included [61]. Furthermore, MD changes in perimenopausal women of different racial descents have been linked to SNPs in genomic loci encoding enzymes controlling sex steroid metabolism and ERs. Since the former act upon and the latter are expressed in breast tissue, such SNPs could therefore impact $\mathrm{BC}$ risk through $\mathrm{MD}$ modulation via the estrogen/ER interaction [62]. Additionally, recent analysis of known BC susceptibility genes has identified two novel MD loci in 6q25.1 region, one of which is in the TAB2 gene [63], a potential driver of tamoxifen resistance [64]. Reduced tamoxifen effectiveness, mediated through these loci, may explain the higher risk of local relapse and contralateral primary $\mathrm{BC}$ associated with higher MD.

Turning to potential proteomic drivers of risk, high MD tissue shows higher expression of proteins involved in angiogenesis, inflammation, proliferation and estrogen synthesis, whereas low MD tissue shows higher expression of effectors of cell cycle arrest and estrogen inactivation [65]. Fibrous stroma of women at high risk of BC was noted to very frequently express ER $\alpha$ regardless of MD status, whereas frequent expression of $\mathrm{PR} \alpha$ was found in the stroma of high MD compared to low MD mammary tissue, and is thus also pathogenically implicated [17].

Considering mammographically dense tissue from the perspective of whole tissue cellular interactions, the influence of MD on breast cells at risk, roles of stromal cells that appear to confer risk, and adipose cells that may confer protection are key questions [60].

Tamoxifen is the most extensively studied ET in both preventive and adjuvant settings for $\mathrm{BC}$ and also the drug with the most consistent links between induced MD change and $\mathrm{BC}$. Therefore, it is worthwhile reviewing the established and possible mechanisms through which tamoxifen could impact both MD and BC. In terms of tamoxifen effects on breast tissue, the drug was noted to cause a reduction in the stromal component of biochamber-implanted HMD tissue, which was associated with reduction of MD [66]. In addition to contributing to an HMD status [67], a high stromal density contributes to a higher $\mathrm{BC}$ risk in animals $[68,69]$. Thus, tamoxifen- induced reduction of stromal density could reduce $\mathrm{BC}$ risk concomitantly with its demonstrated MD lowering effect. Similarly, a reduction in the absolute epithelial mass has been observed in response to tamoxifen treatment in rodents. Such reduction was concomitant with MD reduction [70] and possibly with lower BC events. Additionally, the proliferative state of epithelial cells may affect both MD and the probability of cancerinitiating genetic damage [71]. However, the role of tamoxifen-mediated reduction of stromal and epithelial components in causing reduction of MD-associated breast carcinogenesis is speculative and needs further confirmatory studies.

Looking at specific signalling pathways, a number of pathways that mediate the pathogenesis of $\mathrm{BC}$ and MD have been identified as targets for tamoxifen action. Tamoxifen has been reported to enhance expression of transmembrane receptor CD36 [72], which was found to be repressed both in HMD tissue and in BC [73]. Suppression of Hedgehog signalling in response to tamoxifen has been demonstrated to remodel the stromal micro-environment [74] through down-regulation of stromal fibroblast proliferative activity [75]. A higher proliferative rate of stromal fibroblasts has been implicated in HMD status [76] and higher rate of cancer initiation as well [77]. Tamoxifen was also reported to interfere with IGF1 receptor (IGF-1R) signalling [78]; the expression of which has been found to increase in relation to both $\mathrm{BC}$ and increased MD [79, 80]. Similarly, tamoxifen has been known to reduce circulating IGF-1 [81], which was found to positively correlate with both $\mathrm{BC}$ risk [82] and HMD [83]. Furthermore, tamoxifen treatment of biochamberimplanted HMD tissue has been shown to alter Cox-2 expression in stromal cells [84], which has been found in other studies to be implicated in both MD and tumour initiation [85], adding another possible mechanism of tamoxifen reduction of $\mathrm{MD}$ and associated $\mathrm{BC}$ events.

\section{DISCUSSION}

\section{MD modification on ET}

Across the spectrum of available studies tamoxifen has been shown to reduce MD in a significant proportion of participants, which has allowed further analysis of these changes in relation to efficacy. The degree and direction of change on raloxifene is more heterogeneous with significant MD reduction not being seen in any study. Whether this represents a subtly different mechanism of action or lower potency and efficacy, as suggested by the previously referenced STAR trial, is unclear. Significant MD changes on AIs have not been frequently observed; which could suggest that AIs may exert their therapeutic effect through non-MD mediated mechanisms. 
Additionally, as AIs are only indicated as single agents in the postmenopausal setting where baseline MD tends to be low, this may also explain why their effects on MD are not significant. In keeping with this, most studies have observed that MDR was more substantial in women having initially higher MD $[27,86,87]$. Whether a longer period of observation is useful to capture more significant change is unknown, although a significant prolongation of time to acquisition of a usable efficacy prediction would obviously diminish clinical utility.

\section{MD change in premenopausal women}

Both the likelihood and the magnitude of ETinduced MD reduction have been universally observed to be greater among pre-menopausal women, at least in part due to their higher baseline MD at study entry time, which is attributable to higher ovarian estrogen production. Additionally, pre-menopausal women are generally younger and tend to be more physically active, thus possibly having lower BMI. Both factors, younger age [56] and lower BMI [27], have been demonstrated in multivariate analysis to be significant independent predictors of greater MD reduction. It is thus expected that the potential for MD change as an ET-monitoring tool would be greatest among this subgroup of women.

\section{MD as a predictive surrogate in primary prevention}

The uptake of tamoxifen in primary prevention by women at high risk of $\mathrm{BC}$ is low with less than $5 \%$ of high risk women utilising this approach [88]. Confirmation of the provocative findings relating to MD change and benefit seen in IBIS I in a second study utilising tamoxifen would assist in bringing MD assessment into clinical practice and could significantly improve preventative tamoxifen uptake. The optimal trial design would explore a strategy of continuation or discontinuation of preventative treatment based on MD change relative to continued therapy regardless of MD alterations, and would measure subsequent $\mathrm{BC}$ risk. Extension of research into prevention studies employing AIs such as IBIS II [7] or MAP.3 [42] would both clarify the role of MD change with this class of agent and add a valuable prediction tool across the future $\mathrm{BC}$ prevention landscape. If positive, this could particularly guide personalised prevention allowing tailoring towards the most effective agent for the individual; SERM or AI.

\section{MD modulation in adjuvant studies}

Considering the observations that initial MD can predict the risk of second primary and local relapse, this supports the hypothesis that tamoxifen-induced MD reduction may, at least in part, reflect improvements in $\mathrm{BC}$ outcome through modulation of the effects of the local breast environment on developing or residual malignant cells.

Across the adjuvant tamoxifen studies, particularly in younger women, the predictive power of MD change appears consistent and robust. However, all studies to date have failed to account for important potential confounders. An important example of such confounders is chemotherapy treatment, which frequently induces menopause in treated pre-menopausal patients. The resultant reduction in ovarian hormonal output can significantly improve $\mathrm{BC}$ outcomes, as most recently evidenced by the SOFT trial in women still premenopausal after chemotherapy [89], and would also be expected to bring about a reduction in MD. In this regard it is noteworthy that the two largest studies by Kim et al [57] and Ko et al [56] had mean ages of 49 and 45 years and chemotherapy delivery rates of $77 \%$ and $68 \%$ respectively, suggesting that chemotherapy-induced menopause would have been a frequent occurrence. Chemotherapyinduced menopause should, therefore, be accounted for in correlative analyses of MD reduction and protective benefit to exclude this confounder as the driver of MDRprotective benefit correlation. Furthermore, older women ceasing hormone replacement therapy (HRT) at diagnosis could also experience prognostically important MD falls independent of ET effect. Interim analysis was recently presented of research undertaken by members of our group examining the predictive power of MD fall in the first 921 patients of a 1942 adjuvant ET-treated retrospective cohort [58]. Full data on chemotherapy-induced menopause and HRT cessation are available for this study cohort and will be factored into the final analysis.

The value of MDR as a predictor of AI efficacy is less clear. In the larger retrospective study of Kim et al [57], MDR had similar predictive power for AI and tamoxifen usage. The study by members of our group mirrored this; patients on tamoxifen and AIs experienced numerically close MDRs, which have been subsequently found to correlate significantly with DFS in the entire cohort, suggesting therefore that MDR could be predictive of AI efficacy as well. The detailed results however are yet to be reported in the final analysis [58]. In contrast, in the study of Van Nes et al of patients from the prospective TEAM study, infrequent MDRs and a lack of correlation with outcome were observed [59]. The reason for this heterogeneity is unclear. The most common AIs in general use, and used in the study of Kim et al, are the non-steroidal AIs (NSAIs) letrozole and anastrozole. In contrast, the negative study [59] employed exclusively exemestane. Inter-agent differences in effect on MD are thus a possibility although efficacy differences have not been seen in head-to-head trials between AIs. Exploring alternative explanations, it is noteworthy that $77 \%$ of 
patients in the study of Kim et al received chemotherapy and thus a proportion of patients may have received an AI following on from chemotherapy-induced menopause, a time at which MD often falls. Again in contrast, the TEAM study required patients to have confirmed menopause at study entry and hence may have been further from menopause with consequently lower MD, making resultant changes smaller on treatment. Additionally, high $\mathrm{BMI}$ can confound AI efficacy and also interact with MD. On the TEAM study, $61 \%$ of this older European-derived patient population was overweight or obese. BMI was not reported in the study of Kim et al, but might be expected to be significantly lower in a younger Korean population, raising the possibility that BMI might differentially modulate AI efficacy and explain inter-trial MD change discrepancies. Contrary to this, the BMI demographic in the Australian study by members of our group was more reflective of the TEAM population with $65 \%$ overweight or obese but still showing measurable MD falls in the entire cohort, including those on AIs.

It is also worth considering the biology behind the association between MDR and BC outcome, particularly for distant relapse $[56,57]$ and mortality $[53,54]$ in the adjuvant setting. Here, presumptive micro-metastases are established prior to definitive surgery in non-breast tissues. MD change could either be a specific surrogate for the influence of ET on non-breast tissues or a broader surrogate for favourable pharmacokinetics such as increased drug activation, longer retention or reduced deactivation. On the former point, there is little cancer-specific data although estrogen and anti-estrogens are well known to influence bone biochemistry, a common metastatic site. On the latter point, a clinically relevant possibility is that MD change may predict tamoxifen activation status. Cytochrome P450 2D6 enzyme (CYP2D6) metabolizer status influences such activation, with poor metabolisers (PMs) showing a degree of tamoxifen resistance. Extensive metabolizers, rather than PMs, were more likely to have a greater than $10 \%$ MD reduction in 12 month post treatment mammogram [90] and have been found in some studies to have improved outcomes [91], although results have been inconsistent, possibly due to molecular heterogeneity in other tamoxifen-metabolising enzymes [92]. As a potential marker of tamoxifen activation, MD change bypasses the need both for a detailed understanding of and complex testing for such enzyme variants.

\section{Insights from the pathobiological links between $\mathrm{MD}, \mathrm{BC}$ risk and $\mathrm{ET}$ action}

Reassuringly, a number of known mechanisms of pathogenic importance to $\mathrm{BC}$ have been found to be interlinked with $\mathrm{MD}$, including key signalling pathways, enhancers of motility, angiogenesis and inflammation, which further validate $\mathrm{MD}$ as intrinsic to $\mathrm{BC}$ development.
The identification of specific molecules within these functional domains may indicate that these molecules are particularly important to oncogenesis and thereby, could elevate them to suitable drug targets. For example, the TAB2 protein is implicated in disrupting co-repressor binding to ERs in response to tamoxifen, preventing tamoxifen-driven transcriptional suppression [64]. High MD and $\mathrm{BC}$ risk linked to polymorphisms in this molecule may arise from an impact on the co-repressor:coactivator balance in normal health, increasing the impact of estrogens on normal tissues including the breast [63]. Attenuating this function could be explored in prevention and treatment in women with high MD.

\section{MD evaluation modalities and radiation exposure}

Various imaging modalities have been developed to evaluate MD, among which X ray-based and MR-based modalities are the best established [93]. On the balance of cost effectiveness and measurement efficiency, digital mammography $(\mathrm{DM})$ is the most commonly utilized in clinical practice, with continuous advancement in MD measurement software. Although the involved radiation risk is generally small, the issue becomes a concern when taking into account that the mammographic examination is taking place in basically asymptomatic woman in the preventative setting. A recent study by Al Kattar et al [94] demonstrated that the mean glandular radiation dose (MGD) delivered from DM as measured in a standard breast phantom was at most $2.05 \mathrm{mGy}$ at an average thickness of $50 \mathrm{~mm}$, which is far less than maximal MGD accepted in the AFSSAPS 2006 report and FDA allowable limit of 3 mGy per exposure [95]. From a clinical perspective, the lifetime risk of $\mathrm{BC}$ incidence attributed to 2D bilateral screening mammography in 40 year woman has been estimated to be 5-7/100000 [96].

\section{Is MD ready for prime time?}

The promise of MD utility and the lack of timely alternatives have encouraged many researchers to consider MD as a surrogate for risk of $\mathrm{BC}$ events [97] and to set it as a secondary $[98,99]$ or even as a primary endpoint [100] in clinical trials including those evaluating AIs in the preventive setting [101], but is this confidence in the potential of MD change as a prediction tool justified?

The potential for MD to guide $\mathrm{BC}$ intervention has long been recognised [102]. As opposed to tissue and circulating biomarkers [103], MD is particularly appealing since it; 1) significantly correlates with both BC risk and outcomes, 2) significantly changes in response to some endocrine manipulations, 3 ) is non-invasive, and 4) may be easily incorporated in the routine care already employed in screening and follow up of BC; thereby, minimising additional cost. However, a cancer biomarker 
should not be introduced into clinical utility before it has been validated and before methods and protocols have been optimised for effective widespread usage.

For predictive markers that may change treatment decisions, validation has to be rigorous as described by Prentice et al [104] and subsequently emphasized by the Boyd group [105, 106]. The National Cancer Institute of USA has outlined a strategy for biomarker discovery and development consisting of three phases. Phase I incorporates biomarker discovery, assay development and initial small pilot studies, all relatively well covered for MD in BC. Phase II undertakes the study of large independent retrospective cohorts, as reviewed here (Table 3). Phase III involves both the retrospective analysis of material or data from prospective clinical trials as reported here for the IBIS I primary prevention study [48] moving forward to new prospective clinical trials where the biomarker will be employed for decision making in the experimental arm and outcomes are compared with standard practice in the control arm.

Considering the adjuvant scenario where the intuitive utility of MD monitoring is to guide switching between SERM and AI, a retrospective analysis of the BIG 1 study where large cohorts received treatment with AI alone, SERM alone, AI followed by SERM or vice versa [107], appears to be well indicated. If patients with no significant MD change on initial therapy show better outcomes after switching than those with similar MD dynamics randomised to remain on the same initial therapy, this could pave the way for a prospective trial using MD change to tailor therapy type with the potential to improve BC outcomes.

Additionally, before MD change can be introduced as a predictive biomarker into the clinical practice, some more pragmatic knowledge gaps also need to be filled:

1) What MDR threshold best predicts outcome improvement?

2) What is the most accurate predicting MD parameter i.e. percent density (in terms of area $v s$. volume) vs. absolute measures (e.g. dense area) vs. categorical density (in terms of BIRADS vs. Boyd's vs. Wolf's categories)?

3) What is the best (accurate and feasible) MD interpretation method i.e. visual vs. computer assisted $v s$. fully automated methods?

\section{MATERIALS AND METHODS}

Relevant literature was identified by an interrogation of Embase and Medline electronic databases using the Ovid interface. Our strategy consisted of searching in (all fields), using keywords extracted from the relevant $\mathrm{MeSH}$ headings, which were then combined using the Boolean operators, leading to the search terms: [(mammographic density) AND (receptor modulat* OR arzoxifen* OR lasofoxifen* OR raloxifen* OR tamoxifen*)] and [(mammographic density) AND (aromatase inhibit* OR anastrozol* OR letrozol* OR exemestan*)]. Limitations applied were: 1) English literature, 2) publication year (2000 - current). Full text manuscripts of relevant records were assessed for eligibility. Eligible articles were those investigating $\mathrm{BC}$ risk or outcomes and $\mathrm{MD}$ changes in relation to ETs in the preventive or adjuvant $\mathrm{BC}$ scenarios. Additional articles were retrieved either from relevant article bibliographies or from Pubmed for the monitoring biomarker section. Relevant data from an interim analysis of a study by members of our group were also included. A total of 107 eligible publications were identified and used to construct this review.

\section{CONCLUSIONS}

MD change over the ET course, rather than a single MD measurement, can predict risk or outcome modifications in $\mathrm{BC}$ preventive and adjuvant settings with certain restrictions. MD reduction is relatively frequent for patients on tamoxifen, with reasonable evidence in both primary and secondary preventative settings that this correlates with risk reduction. The situation with other SERMs and AIs is unclear with further, larger studies required. Analyses in this area should take account of the potential effects of patients entering menopause or stopping HRT, which may confound results. Development of MD as a biomarker appears relatively well advanced through the later Phase II or early Phase III stages of the NCI biomarker development scheme. Retrospective analysis of prospective trials and subsequent employment of MD in future prospective randomised trials is now required to advance the field towards clinical utility. Additionally, studies are also needed to fill the aforementioned knowledge gaps to define the optimum elements of MD to assess and the method of measurement to employ, to ensure reproducibility across health systems. Further research, exploring the pathobiological relation between $\mathrm{MD}$ and $\mathrm{BC}$ may also assist in new target discovery and the consequent development of novel therapeutics.

\section{Abbreviations}

AI: Aromatase inhibitor; BC: Breast cancer; EGF: Epidermal growth factor; ER: Estrogen receptor; ET: Endocrine therapy; HMD: High mammographic density; LMD: Low mammographic density; IGF 1: Insulin-like growth factor 1; IGF1-R: IGF1 receptor; MD: Mammographic density; MDR: MD reduction; PR: Progesterone receptor; SERM: Selective ER modulator; SNP: Single nucleotide polymorphism. 


\section{ACKNOWLEDGMENTS}

M.S.S would like to thank the Ministry of Higher Education- Missions sector, Egypt and the British Council for their support through Newton-Musharafa programme via the Egyptian Cultural Bureau in London. This work was supported in part by the Victorian Breast Cancer Research Consortium, the St. Vincent's Hospital (Melbourne) Research Endowment Fund, the National Breast Cancer Foundation and the University of Melbourne Research Grant Support Scheme (MRGSS), the Translational Research Institute (TRI SPORE grant), and the Princess Alexander Hospital Foundation (ALS Breast Cancer Grant), Australia. KB was supported by an NBCF Early Career Fellowship. AR was supported by Clinical Research Fellowship from Cancer Council WA. EWT was supported in part by the NBCF through a National Collaborative Research Network award (CG10-04).

\section{CONFLICTS OF INTEREST}

The authors declare that they have no competing interests.

\section{Author contributions}

MSS researched data for article, wrote the paper and reviewed it before submission. HM contributed data to the article and reviewed/edited it before submission. $\mathrm{HH}, \mathrm{TL}$ and $\mathrm{KB}$ reviewed/edited it before submission. $\mathrm{AR}$ and EWT contributed equally to this work; AR contributed data to the article, substantially contributed to discussion, reviewed/edited the manuscript before submission and EWT supervised the project, substantially contributed to discussion, reviewed/edited the manuscript before submission.

\section{Editorial note}

This paper has been accepted based in part on peerreview conducted by another journal and the authors' response and revisions as well as expedited peer-review in Oncotarget.

\section{REFERENCES}

1. American Cancer Society. Cancer Facts \& Figures 2016. Atlanta: American Cancer Society (2016).

2. Visvanathan K, Hurley P, Bantug E, Brown P, Col NF, Cuzick J, Davidson NE, DeCensi A, Fabian C \& Ford L. Use of pharmacologic interventions for breast cancer risk reduction: American Society of Clinical Oncology clinical practice guideline. J Clin Oncol. 2013; JCO. 2013.49. 3122.
3. Burstein HJ, Temin S, Anderson H, Buchholz TA, Davidson NE, Gelmon KE, Giordano SH, Hudis CA, Rowden D, Solky AJ, Stearns V, Winer EP \& Griggs JJ. Adjuvant endocrine therapy for women with hormone receptor-positive breast cancer: american society of clinical oncology clinical practice guideline focused update. J Clin Oncol. 2014; 32: 2255-69.

4. Folkerd EJ, Lønning PE \& Dowsett M. Interpreting Plasma Estrogen Levels in Breast Cancer: Caution Needed. J Clin Oncol. 2014; 32: 1396-1400.

5. Folkerd E \& Dowsett M. Sex hormones and breast cancer risk and prognosis. Breast. 2013; 22 Suppl 2: S38-43.

6. Cuzick J, Sestak I, Cawthorn S, Hamed H, Holli K, Howell A \& Forbes JF. Tamoxifen for prevention of breast cancer: extended long-term follow-up of the IBIS-I breast cancer prevention trial. Lancet Oncol. 2015; 16: 67-75.

7. Cuzick J, Sestak I, Forbes JF, Dowsett M, Knox J, Cawthorn S, Saunders C, Roche N, Mansel RE, von Minckwitz G, Bonanni B, Palva T \& Howell A. Anastrozole for prevention of breast cancer in high-risk postmenopausal women (IBISII): an international, double-blind, randomised placebocontrolled trial. Lancet. 2014; 383: 1041-8.

8. Effects of chemotherapy and hormonal therapy for early breast cancer on recurrence and 15-year survival: an overview of the randomised trials. Lancet. 2005; 365: 1687717.

9. Huo CW, Chew GL, Britt KL, Ingman WV, Henderson MA, Hopper JL \& Thompson EW. Mammographic density-a review on the current understanding of its association with breast cancer. Breast Cancer Res Treat. 2014; 144: 479-502.

10. Cuzick J. Epidemiology of breast cancer - Selected highlights. Breast. 2003; 12: 405-411.

11. Palomares MR, Machia JR, Lehman CD, Daling JR \& McTiernan A. Mammographic density correlation with Gail model breast cancer risk estimates and component risk factors. Cancer Epidemiol Biomarkers Prev. 2006; 15: 1324-30.

12. Tice JA, Cummings SR, Smith-Bindman R, Ichikawa L, Barlow WE \& Kerlikowske K. Using clinical factors and mammographic breast density to estimate breast cancer risk: development and validation of a new predictive model. Ann Intern Med. 2008; 148: 337-47.

13. Cil T, Fishell E, Hanna W, Sun P, Rawlinson E, Narod SA \& McCready DR. Mammographic density and the risk of breast cancer recurrence after breast-conserving surgery. Cancer. 2009; 115: 5780-7.

14. McTiernan A, Martin CF, Peck JD, Aragaki AK, Chlebowski RT, Pisano ED, Wang CY, Brunner RL, Johnson KC, Manson JE, Lewis CE, Kotchen JM \& Hulka BS. Estrogen-plus-progestin use and mammographic density in postmenopausal women: Women's Health Initiative randomized trial. J Natl Cancer Inst. 2005; 97: 1366-76.

15. Ritte R, Lukanova A, Berrino F, Dossus L, Tjonneland 
A, Olsen A, Overvad TF, Overvad K, Clavel-Chapelon F, Fournier A, Fagherazzi G, Rohrmann S, Teucher B et al. Adiposity, hormone replacement therapy use and breast cancer risk by age and hormone receptor status: a large prospective cohort study. Breast Cancer Res. 2012; 14: R76.

16. Greendale GA, Palla SL, Ursin G, Laughlin GA, Crandall C, Pike MC \& Reboussin BA. The association of endogenous sex steroids and sex steroid binding proteins with mammographic density: results from the Postmenopausal Estrogen/Progestin Interventions Mammographic Density Study. Am J Epidemiol. 2005; 162: 826-834.

17. Pang JM, Byrne DJ, Takano EA, Jene N, Petelin L, McKinley J, Poliness C, Saunders C, Taylor D, Mitchell G \& Fox SB. Breast Tissue Composition and Immunophenotype and Its Relationship with Mammographic Density in Women at High Risk of Breast Cancer. PLoS One. 2015; 10: e0128861.

18. Biomarkers and surrogate endpoints: preferred definitions and conceptual framework. Clin Pharmacol Ther. 2001; 69: 89-95.

19. Mahoney KM \& Atkins MB. Prognostic and predictive markers for the new immunotherapies. Oncology (Williston Park, NY). 2014; 28: 39-48.

20. Katz R. Biomarkers and Surrogate Markers: An FDA Perspective. NeuroRx. 2004; 1: 189-195.

21. Mandrekar SJ \& Sargent DJ. Predictive biomarker validation in practice: lessons from real trials. Clin Trials. 2010; 7: 567-573.

22. Singletary SE. Rating the risk factors for breast cancer. Ann Surg. 2003; 237: 474-482.

23. Fitzpatrick DJ, Lai CS, Parkyn RF, Walters D, Humeniuk V \& Walsh DC. Time to breast cancer relapse predicted by primary tumour characteristics, not lymph node involvement. World J Surg. 2014; 38: 1668-75.

24. Fabian JC \& Kimler FB. in Novel Biomarkers in the Continuum of Breast Cancer (ed. Stearns, V.) 69-94 (Springer International Publishing, Cham, 2016).

25. Rastelli F \& Crispino S. Factors predictive of response to hormone therapy in breast cancer. Tumori. 2008; 94: 37083.

26. Yamashita H, Nishio M, Ando Y, Zhang Z, Hamaguchi M, Mita K, Kobayashi S, Fujii Y \& Iwase H. Stat5 expression predicts response to endocrine therapy and improves survival in estrogen receptor-positive breast cancer. Endocr Relat Cancer. 2006; 13: 885-93.

27. Cuzick J, Warwick J, Pinney E, Warren RM \& Duffy SW. Tamoxifen and breast density in women at increased risk of breast cancer. J Natl Cancer Inst. 2004; 96: 621-8.

28. Brisson J, Brisson B, Coté G, Maunsell E, Bérubé S \& Robert J. Tamoxifen and Mammographic Breast Densities. Cancer Epidemiol Biomarkers Prev. 2000; 9: 911-915.

29. Chow CK, Venzon D, Jones EC, Premkumar A, O'Shaughnessy J \& Zujewski J. Effect of Tamoxifen on Mammographic Density. Cancer Epidemiol Biomarkers
Prev. 2000; 9: 917-921.

30. Meggiorini ML, Labi L, Vestri AR, Porfiri LM, Savelli S \& De Felice C. Tamoxifen in women with breast cancer and mammographic density. Eur J Gynaecol Oncol. 2008; 29: 598-601.

31. Konez O, Goyal M \& Reaven RE. Can tamoxifen cause a significant mammographic density change in breast parenchyma? Clin Imaging. 2001; 25: 303-8.

32. Engmann NJ, Vachon CM, Scott CG, Jensen MR, Ma L, Brandt KR, Mahmoudzadeh AP, Malkov S, Whaley DH \& Hruska CB. Longitudinal changes in volumetric breast density with adjuvant endocrine therapy among women with breast cancer. Cancer Res. 2016; 76: 3424-3424.

33. Howell A, Astley S, Harkness E, Wiseman J, Fox J, Stavrinos P, Wilson M, Lim Y, Reece V, Beetles U, Jain A, Sergeant J, Cuzick J et al. Abstract P5-12-01: Predicting the effect of tamoxifen on the breast: Change in measures of breast density, serum markers and SNPs. Cancer Res. 2015; 75: P5-12-01.

34. Harvey JA, Pinkerton JV, Baracat EC, Shi H, Chines AA \& Mirkin S. Breast density changes in a randomized controlled trial evaluating bazedoxifene/conjugated estrogens. Menopause. 2013; 20: 138-45.

35. Nielsen M, Raundahl J, Pettersen PC, Loog M, Karemore G, Karsdal MA \& Christiansen C. Low-dose transdermal estradiol induces breast density and heterogeneity changes comparable to those of raloxifene. Menopause. 2009; 16: 785-91.

36. Eilertsen AL, Karssemeijer N, Skaane P, Qvigstad E \& Sandset PM. Differential impact of conventional and lowdose oral hormone therapy, tibolone and raloxifene on mammographic breast density, assessed by an automated quantitative method. BJOG. 2008; 115: 773-9.

37. Cirpan T, Akercan F, Itil IM, Gundem G, Bilgen I \& Yucebilgin MS. Does raloxifene therapy affect mammographic breast cancer screening in postmenopausal patients? Eur J Gynaecol Oncol. 2006; 27: 177-8.

38. Christodoulakos GE, Lambrinoudaki IV, Vourtsi AD, Panoulis KPC, Kelekis DA \& Creatsas GC. Mammographic changes associated with raloxifene and tibolone therapy in postmenopausal women: A prospective study. Menopause. 2002; 9: 110-116.

39. Freedman M, San Martin J, O'Gorman J, Eckert S, Lippman ME, Lo SC, Walls EL \& Zeng J. Digitized mammography: a clinical trial of postmenopausal women randomly assigned to receive raloxifene, estrogen, or placebo. J Natl Cancer Inst. 2001; 93: 51-6.

40. Eng-Wong J, Orzano-Birgani J, Chow CK, Venzon D, Yao J, Galbo CE, Zujewski JA \& Prindiville S. Effect of raloxifene on mammographic density and breast magnetic resonance imaging in premenopausal women at increased risk for breast cancer. Cancer Epidemiol Biomarkers Prev. 2008; 17: 1696-701.

41. Vogel VG, Costantino JP, Wickerham DL, Cronin WM, 
Cecchini RS, Atkins JN, Bevers TB, Fehrenbacher L, Pajon ER, Wade JL, 3rd, Robidoux A, Margolese RG, James J et al. Update of the National Surgical Adjuvant Breast and Bowel Project Study of Tamoxifen and Raloxifene (STAR) P-2 Trial: Preventing breast cancer. Cancer Prev Res (Phila). 2010; 3: 696-706.

42. Goss PE, Ingle JN, Ales-Martinez JE, Cheung AM, Chlebowski RT, Wactawski-Wende J, McTiernan A, Robbins J, Johnson KC, Martin LW, Winquist E, Sarto GE, Garber JE et al. Exemestane for breast-cancer prevention in postmenopausal women. N Engl J Med. 2011; 364: 238191.

43. Smith J, Dilawari A, Ursin G, Andreopoulou E, Checka C, Axelrod D, Guth A, Toth H, Utate M, Carapetyan K, Reich E, Diflo T \& Muggia F. A pilot study of letrozole for one year in women at enhanced risk of developing breast cancer: effects on mammographic density. Anticancer Res. 2012; 32: 1327-31.

44. Gatti-Mays ME, Venzon D, Galbo CE, Singer A, Reynolds J, Makariou E, Kallakury B, Heckman-Stoddard BM, Korde L, Isaacs C, Warren R, Gallagher A \& Eng-Wong J. Exemestane Use in Postmenopausal Women at High Risk for Invasive Breast Cancer: Evaluating Biomarkers of Efficacy and Safety. Cancer Prev Res (Phila). 2016; 9: 22533.

45. Vachon CM, Ingle JN, Suman VJ, Scott CG, Gottardt H, Olson JE \& Goss PE. Pilot study of the impact of letrozole $v S$. placebo on breast density in women completing 5 years of tamoxifen. Breast. 2007; 16: 204-10.

46. Cigler T, Tu D, Yaffe MJ, Findlay B, Verma S, Johnston D, Richardson H, Hu H, Qi S \& Goss PE. A randomized, placebo-controlled trial (NCIC CTG MAP1) examining the effects of letrozole on mammographic breast density and other end organs in postmenopausal women. Breast Cancer Res Treat. 2010; 120: 427-35.

47. Cigler T, Richardson H, Yaffe MJ, Fabian CJ, Johnston D, Ingle JN, Nassif E, Brunner RL, Wood ME, Pater JL, Hu $\mathrm{H}$, Qi S, Tu D et al. A randomized, placebo-controlled trial (NCIC CTG MAP.2) examining the effects of exemestane on mammographic breast density, bone density, markers of bone metabolism and serum lipid levels in postmenopausal women. Breast Cancer Res Treat. 2011; 126: 453-61.

48. Cuzick J, Warwick J, Pinney E, Duffy SW, Cawthorn S, Howell A, Forbes JF \& Warren RM. Tamoxifen-induced reduction in mammographic density and breast cancer risk reduction: a nested case-control study. J Natl Cancer Inst. 2011; 103: 744-52.

49. Cuzick J, Warwick J, Pinney L, Warren R, Cawthorn S, Howell A \& Duffy S. Change in breast density as a biomarker of breast cancer risk reduction; results from IBIS-1. Cancer Res. 2009; 69: 61.

50. Park CC, Rembert J, Chew K, Moore D \& Kerlikowske K. High mammographic breast density is independent predictor of local but not distant recurrence after lumpectomy and radiotherapy for invasive breast cancer. Int J Radiat Oncol Biol Phys. 2009; 73: 75-9.

51. Ozhand A, Mckean-Cowdin R, Bernstein L, Ballard-Babash R, McTiernan A \& Baumgartner KB. Abstract 2286: Short term reduction in mammographic density predicts survival in breast cancer. Cancer Res. 2013; 73: 2286.

52. Habel LA, Capra AM, Achacoso NS, Janga A, Acton L, Puligandla B \& Quesenberry CP, Jr. Mammographic density and risk of second breast cancer after ductal carcinoma in situ. Cancer Epidemiol Biomarkers Prev. 2010; 19: 2488-95.

53. Nyante SJ, Sherman ME, Pfeiffer RM, Berrington de Gonzalez A, Brinton LA, Aiello Bowles EJ, Hoover RN, Glass A \& Gierach GL. Prognostic significance of mammographic density change after initiation of tamoxifen for ER-positive breast cancer. J Natl Cancer Inst. 2015; 107:

54. Li J, Humphreys K, Eriksson L, Edgren G, Czene K \& Hall P. Mammographic density reduction is a prognostic marker of response to adjuvant tamoxifen therapy in postmenopausal patients with breast cancer. J Clin Oncol. 2013; 31: 2249-56.

55. Sandberg MEC, Li J, Hall P, Hartman M, dos-Santos-Silva I, Humphreys K \& Czene K. Change of mammographic density predicts the risk of contralateral breast cancer - a case-control study. Breast Cancer Res. 2013; 15: R57-R57.

56. Ko KL, Shin IS, You JY, Jung S-Y, Ro J \& Lee ES. Adjuvant tamoxifen-induced mammographic breast density reduction as a predictor for recurrence in estrogen receptorpositive premenopausal breast cancer patients. Breast Cancer Res Treat. 2013; 142: 559-567.

57. Kim J, Han W, Moon HG, Ahn S, Shin HC, You JM, Han SW, Im SA, Kim TY, Koo H, Chang J, Cho N, Moon W et al. Breast density change as a predictive surrogate for response to adjuvant endocrine therapy in hormone receptor positive breast cancer. Breast Cancer Res. 2012; 14: R102.

58. Martin HL, Yap F, Chung K, Stone J, Redfern AD. Mammographic breast density as a predictor of hormone receptor positive breast cancer recurrence: A single centre longitudinal analysis. PD1-06 SABCS, Dec 2015.

59. van Nes JG, Beex LV, Seynaeve C, Putter H, Sramek A, Lardenoije S, Duijm-de Carpentier M, Van Rongen I, Nortier JW, Zonderland HM \& van de Velde CJ. Minimal impact of adjuvant exemestane or tamoxifen treatment on mammographic breast density in postmenopausal breast cancer patients: a Dutch TEAM trial analysis. Acta Oncol. 2015; 54: 349-60.

60. Pettersson A \& Tamimi RM. Breast density and breast cancer risk: understanding of biology and risk. Curr Epidemiol Rep. 2014; 1: 120-129.

61. Lindstrom S, Thompson DJ, Paterson AD, Li J, Gierach GL, Scott C, Stone J, Douglas JA, dos-Santos-Silva I, Fernandez-Navarro P, Verghase J, Smith P, Brown J et al. Genome-wide association study identifies multiple loci associated with both mammographic density and breast 
cancer risk. Nat Commun. 2014; 5: 5303.

62. Crandall CJ, Sehl ME, Crawford SL, Gold EB, Habel LA, Butler LM, Sowers MR, Greendale GA \& Sinsheimer JS. Sex steroid metabolism polymorphisms and mammographic density in pre- and early perimenopausal women. Breast Cancer Res. 2009; 11: R51.

63. Brand JS, Li J, Humphreys K, Karlsson R, Eriksson M, Ivansson E, Hall P \& Czene K. Identification of two novel mammographic density loci at 6Q25.1. Breast Cancer Res. 2015; 17: 75.

64. Cutrupi S, Reineri S, Panetto A, Grosso E, Caizzi L, Ricci L, Friard O, Agati S, Scatolini M, Chiorino G, Lykkesfeldt AE \& De Bortoli M. Targeting of the adaptor protein Tab2 as a novel approach to revert tamoxifen resistance in breast cancer cells. Oncogene. 2012; 31: 4353-61.

65. Hanna M \& Diorio C. Does mammographic density reflect the expression of breast cancer markers? Climacteric. 2013; 16: 407-16.

66. Chew GL, Huo CW, Huang D, Blick T, Hill P, Cawson J, Frazer H, Southey MC, Hopper JL, Britt K, Henderson MA, Haviv I \& Thompson EW. Effects of Tamoxifen and oestrogen on histology and radiographic density in high and low mammographic density human breast tissues maintained in murine tissue engineering chambers. Breast Cancer Res Treat. 2014; 148: 303-14.

67. Huo CW, Chew G, Hill P, Huang D, Ingman W, Hodson L, Brown KA, Magenau A, Allam AH, McGhee E, Timpson P, Henderson MA, Thompson EW et al. High mammographic density is associated with an increase in stromal collagen and immune cells within the mammary epithelium. Breast Cancer Res. 2015; 17: 79.

68. Conklin MW \& Keely PJ. Why the stroma matters in breast cancer: insights into breast cancer patient outcomes through the examination of stromal biomarkers. Cell Adh Migr. 2012; 6: 249-60.

69. Liu X, Wu H, Byrne M, Jeffrey J, Krane S \& Jaenisch R. A targeted mutation at the known collagenase cleavage site in mouse type I collagen impairs tissue remodeling. J Cell Biol. 1995; 130: 227-237.

70. McGinley JN \& Thompson HJ. Quantitative assessment of mammary gland density in rodents using digital image analysis. Biol Proced Online. 2011; 13: 4.

71. Boyd NF, Martin LJ, Yaffe MJ \& Minkin S. Mammographic density and breast cancer risk: current understanding and future prospects. Breast Cancer Res. 2011; 13: 223.

72. Saibara T, Ogawa Y \& Onishi S. Tamoxifen in early breast cancer. Lancet. 1998; 352: 404.

73. DeFilippis RA, Chang H, Dumont N, Rabban JT, Chen Y-Y, Fontenay GV, Berman HK, Gauthier ML, Zhao J \& $\mathrm{Hu}$ D. CD36 repression activates a multicellular stromal program shared by high mammographic density and tumor tissues. Cancer discov. 2012; 2: 826-839.

74. Ironside A, Gomm J, Haywood L, Dreger S, Allen M,
Guerra A, Wang J, Chelala C \& Jones JL. Molecular mediators of mammographic density. J Pathol. 2015; 237: S18.

75. Hatsell S \& Frost AR. Hedgehog signaling in mammary gland development and breast cancer. J Mammary Gland Biol Neoplasia. 2007; 12: 163-73.

76. Britt $\mathrm{K}$, Ingman $\mathrm{W}$, Huo $\mathrm{C}$, Chew $\mathrm{G} \&$ Thompson E. The pathobiology of mammographic density. J Cancer Biol Res. 2014; 2: 1021.

77. Kalluri R \& Zeisberg M. Fibroblasts in cancer. Nat Rev Cancer. 2006; 6: 392-401.

78. Guvakova MA \& Surmacz E. Tamoxifen interferes with the insulin-like growth factor I receptor (IGF-IR) signaling pathway in breast cancer cells. Cancer Res. 1997; 57: 260610.

79. Shimizu C, Hasegawa T, Tani Y, Takahashi F, Takeuchi M, Watanabe T, Ando M, Katsumata N \& Fujiwara Y. Expression of insulin-like growth factor 1 receptor in primary breast cancer: immunohistochemical analysis. Hum Pathol. 2004; 35: 1537-42.

80. Sun WY, Yun HY, Song YJ, Kim H, Lee OJ, Nam SJ \& Koo JS. Insulin-like growth factor 1 receptor expression in breast cancer tissue and mammographic density. Mol Clin Oncol. 2015; 3: 572-580.

81. Pollak MN, Huynh HT \& Lefebvre SP. Tamoxifen reduces serum insulin-like growth factor I (IGF-I). Breast Cancer Res Treat. 1992; 22: 91-100.

82. The Endogenous Hormones Breast Cancer Collaborative Group. Insulin-like growth factor 1 (IGF1), IGF binding protein 3 (IGFBP3), and breast cancer risk: pooled individual data analysis of 17 prospective studies. Lancet Oncol. 2010; 11: 530-542.

83. Bremnes Y, Ursin G, Bjurstam N, Rinaldi S, Kaaks R \& Gram IT. Insulin-like growth factor and mammographic density in postmenopausal Norwegian women. Cancer Epidemiol Biomarkers Prev. 2007; 16: 57-62.

84. Chew GL, Huo CW, Huang D, Hill P, Cawson J, Frazer H, Hopper JL, Haviv I, Henderson MA, Britt K \& Thompson EW. Increased COX-2 expression in epithelial and stromal cells of high mammographic density tissues and in a xenograft model of mammographic density. Breast Cancer Res Treat. 2015; 153: 89-99.

85. Huang J, Zhang D, Xie F \& Lin D. The potential role of COX-2 in cancer stem cell-mediated canine mammary tumor initiation: an immunohistochemical study. J Vet Sci. 2015; 16: 225-31.

86. Nyante SJ, Sherman ME, Pfeiffer RM, Berrington A, Brinton LA, Bowles EA, Hoover RN, Glass AG \& Gierach GL. Abstract A32: Patterns of longitudinal change in mammographic density among tamoxifen users. Cancer Prev Res. 2013; 6: A32.

87. Nyante SJ, Sherman ME, Pfeiffer RM, Berrington de Gonzalez A, Brinton LA, Bowles EJ, Hoover RN, Glass 
A \& Gierach GL. Longitudinal Change in Mammographic Density among ER-Positive Breast Cancer Patients Using Tamoxifen. Cancer Epidemiol Biomarkers Prev. 2016; 25: 212-6.

88. Crew KD. Addressing barriers to uptake of breast cancer chemoprevention for patients and providers. Am Soc Clin Oncol Educ Book. 2015; e50-8.

89. Francis PA, Regan MM, Fleming GF, Lang I, Ciruelos E, Bellet M, Bonnefoi HR, Climent MA, Da Prada GA, Burstein HJ, Martino S, Davidson NE, Geyer CE, Jr. et al. Adjuvant ovarian suppression in premenopausal breast cancer. N Engl J Med. 2015; 372: 436-46.

90. Li J, Czene K, Brauch H, Schroth W, Saladores P, Li Y, Humphreys K \& Hall P. Association of CYP2D6 metabolizer status with mammographic density change in response to tamoxifen treatment. Breast Cancer Res. 2013; 15: R93.

91. Jung JA \& Lim HS. Association between CYP2D6 genotypes and the clinical outcomes of adjuvant tamoxifen for breast cancer: a meta-analysis. Pharmacogenomics. 2014; 15: 49-60.

92. Binkhorst L, Mathijssen RH, Jager A \& van Gelder T. Individualization of tamoxifen therapy: much more than just CYP2D6 genotyping. Cancer Treat Rev. 2015; 41: 28999.

93. Chen J-H, Gulsen G \& Su M-Y. Imaging Breast Density: Established and Emerging Modalities. Transl Oncol. 2015; 8: 435-445.

94. Al Kattar Z, El Balaa H, Mazeh Z, Fakih MZ, Shamas N, Eldeen GA, Sleiman F \& Omayrat S. in 2015 International Conference on Advances in Biomedical Engineering (ICABME) 37-40 (IEEE, 2015).

95. (The Mammography Quality Standards Act Final Regulations: Preparing For MQSA Inspections [ [Internet]. US Food and Drug Administration. 2001 [ [ cited 2014 Jul 4]).

96. Hendrick RE. Radiation doses and cancer risks from breast imaging Studies. Radiology. 2010; 257: 246-253.

97. Guerrieri-Gonzaga A, Robertson C, Bonanni B, Serrano D, Cazzaniga M, Mora S, Gulisano M, Johansson H, Intra M, Latronico A, Franchi D, Pelosi G, Johnson K et al. Preliminary results on safety and activity of a randomized, double-blind, 2 X 2 trial of low-dose tamoxifen and fenretinide for breast cancer prevention in premenopausal women. J Clin Oncol. 2006; 24: 129-135.

98. Decensi A. Trial of Low Dose Tamoxifen in Women With Breast Intraepithelial Neoplasia (TAM-01).In: ClinicalTrials.gov [Internet]. Bethesda (MD): National Library of Medicine (US). 2000- [cited 2016 Feb 20]. Available from: http://clinicaltrials.gov/show/ NCT01357772 NLM Identifier: NCT01357772.
99. Decensi A, Gandini S, Serrano D, Cazzaniga M, Pizzamiglio M, Maffini F, Pelosi G, Daldoss C, Omodei U, Johansson H, Macis D, Lazzeroni M, Penotti M et al. Randomized dose-ranging trial of tamoxifen at low doses in hormone replacement therapy users. J Clin Oncol. 2007; 25: 4201-9.

100. University of Alabama at Birmingham. Low-Dose Tamoxifen Citrate in Reducing Breast Cancer Risk in Radiation-Induced Cancer Survivors (LDTam). In: ClinicalTrials.gov [Internet]. Bethesda (MD): National Library of Medicine (US). 2000- [cited 2016 Feb 20]. Available from: http://clinicaltrials.gov/show/ NCT01196936 NLM Identifier: NCT01196936.

101. Dana-Farber Cancer Institute. Letrozole in Preventing Breast Cancer in Postmenopausal Women. In: ClinicalTrials.gov [Internet]. Bethesda (MD): National Library of Medicine (US). 2000- [cited 2016 Feb 20]. Available from: http:// clinicaltrials.gov/show/NCT00090857 NLM Identifier: NCT00090857.

102. Chlebowski RT \& McTiernan A. Biological significance of interventions that change breast density. J Natl Cancer Inst. 2003; 95: 4-5.

103. Sivasubramanian PS \& Crew KD. Biomarker Endpoints for Early-Phase Cancer-Prevention Studies. Curr Breast Cancer Rep. 2013; 5: 194-201.

104. Prentice RL. Surrogate endpoints in clinical trials: definition and operational criteria. Stat Med. 1989; 8: 431-440.

105. Martin LJ, Minkin S \& Boyd NF. Hormone therapy, mammographic density, and breast cancer risk. Maturitas. 2009; 64: 20-6.

106. Boyd NF. Tamoxifen, mammographic density, and breast cancer prevention. J Natl Cancer Inst. 2011; 103: 704-5.

107. Regan MM, Neven P, Giobbie-Hurder A, Goldhirsch A, Ejlertsen B, Mauriac L, Forbes JF, Smith I, Lang I, Wardley A, Rabaglio M, Price KN, Gelber RD et al. Assessment of letrozole and tamoxifen alone and in sequence for postmenopausal women with steroid hormone receptorpositive breast cancer: the BIG 1-98 randomised clinical trial at 8.1 years median follow-up. Lancet Oncol. 2011; 12 : 1101-8. 